\title{
UNITED STATES-SOVIET UNION TRADE AGREEMENT OF 1972
}

\author{
KAZIMIERZ GRZYBOWSKI*
}

General Survey

The 1972 Trade Agreement represents the second occasion on which the United States and the Soviet Union have made an effort to establish a legal regime for economic cooperation between the two countries. The first time, after American recognition of the Soviet Union in 1932, the Commercial Relations Agreement was concluded by the exchange of notes on July $13,1935 .{ }^{1}$ It was made for a year and extended by the yearly exchange of notes until it was terminated in 1951, a casualty of the Cold War era and the agressive Soviet policy towards the West.

The first effort to regularize U.S.Soviet trade relations was an outcome of the political rapproachement between the two countries and the attempt to strengthen the system of collective security threatened by the Axis. The Trade Agreement was only a part of a broader design, which also included a settlement of claims by the Soviet Union arising from the nationalization of American property in Russia.

In this respect, the I972 agreements bear a striking resemblance to the deal made in the thirties. During his visit in Moscow President Nixon and Soviet leaders agreed on certain basic principles to be followed in Soviet-American relations. The Agreement on Principles ${ }^{2}$ was followed by a settlement of American claims from the LendLease Agreement, ${ }^{3}$ and by the Trade ${ }^{4}$ and Maritime Agreements ${ }^{5}$ setting up a legal framework for U.S.U.S.S.R. economic cooperation. As in the thirties, the 1972 agreements are only a part of a broader action to reduce the threat of mutual annihilation, and to establish some measure of cooperation to assure peace and security in the contemporary world.

As all historical analogies, this also is imperfect, since the political situation today, as it determines the role of the United States and of the Soviet Union in the international arena, is far more complex and involved. It remains true, nevertheless, that the economic agreements of 1972 are part of a broader political settlement, the payoff of which cannot be measured exclusively in terms of exports and imports, credits and balance of payments, and mutual benefits which the economies of the two countries will receive from their cooperation.

\footnotetext{
- Professor of Law, Duke University.

${ }^{1}$ Commercial Relations Agreement with the Soviet Union, July 13, 1935, I62 L.N.T.S. 92.

266 Dep'T STATE BULI. $9 \mathrm{I} 8 \mathrm{ff}$. [hereinafter cited as - BuLI. -].

67 BOLL. 603 .

'ld. at 595.

${ }^{5} \mathrm{Id}$. at 664 .
} 
Here, however, analogies end. While the 1935 exchange of notes was a simple arrangement between the two states to grant each other a most-favored-nation clause, the 1972 Trade Agreement is a different matter. In the first place, the Agreement is supported by a number of annexes and exchanges of letters which deal with various provisions of the Agreement and procedures for their implementation. ${ }^{8}$ It takes full account-which the $x 935$ Agreement did not-of the fact that trade between a planned economy and a free market country represents specific problems requiring guarantees and providing for trading techniques which have no application on the world markets in general. The Agreement also acknowledges, albeit discreetly, that some inequities in the position of the participants in Soviet-American trade are unavoidable.

There are three major factors which cause these inequities. The first is that Soviet imports and exports are not controlled by the needs of the Soviet society but by the economic plan. The second is that there is no market in the true sense in the Soviet Union, which of course gives a different meaning to the most-favored-nation clause as compared to its role in the United States. The third factor is that Soviet traders are government agencies, which in their business activities are bound by government policy and act for their State, while American' interests are concerned with making profits for their companies and establishing themselves on the Soviet market.

All these aspects which are so vital for the meaningful foreign trade arrangements between free market and planned economy countries were not taken care of in the I935 arrangements. They did receive full attention in 1972, however. Not only does the 1972 Trade Agreement provide for the mutual grant of the most-favored-nation clause, but it also creates a foreign trade mechanism to handle trade relations between the two countries. The Trade Agreement provides a legal regime controlling commercial transactions and defines the status of American traders in the Soviet Union and vice-versa. It contains an agreement as regards the preferred method for the resolution of disputes between the parties. It also sets certain targets for the volume of trade to be reached within the triennium for which the Agreement was made and points to the areas of economic and commercial activity where cooperation between the American and Soviet "business" circles would be particularly welcome. In other words, while the 1935 Agreement was a very simple document, the 1972 Trade Agreement tries to find answers to various problems which foreign trade operations of other countries with the Soviet Union have laid bare.

Negotiators of trade agreements between market economy countries may confidently refer various aspects of commercial transactions to the legal regimes of the countries involved, which will be either identical or differ but little in determining legal aspects of contracts and the rights of the parties. It would not be necessary, for instance, to assure in the treaty that natural persons may sue in the courts of the

\footnotetext{
'The Trade Agreement consists of the text of the Agreement, Annex I on Procedures for the Implementation of article 3 (dumping), Annex 2 on the Status of the Commercial Office of the United States of America in the Union of Soviet Socialist Republics, Annex 3 on the Status of the Trade Representation of Soviet Socialist Republics in the United States of America, and five exchanges of letters concerning related matters mentioned in the Agreement.
} 
parties in connection with foreign trade transactions or to provide a separate procedure for the licensing of patents to foreign entrepreneurs. Such community of legal regimes cannot be presumed to exist between the market and planned economy countries; their negotiations require a broader approach to legal problems connected with foreign trade transactions and mutual concessions in order to preserve the fundamental characteristics of the legal regimes involved. In the concrete case, Soviet law does not permit a Soviet natural person to make a contract in the United States for the import or export of commodities. An American natural person may, however, make such a contract in the Soviet Union. Under American law, foreign nationals can engage in business activities in the United States, while Americans are permitted to make deals only in the area of foreign trade in the Soviet Union. Hence, there is the need to negotiate not only traditional provisions of a trade agreement but also mutual concessions in the legal systems of two countries with different systems of property relations.

\section{II}

\section{The Mechanism of Trade}

The art of trading with the Soviet Union has been practiced in the free world for over fifty years. Forms of trade and navigation agreements between the Soviet Union and free economy countries, in particular regulations regarding the mechanism of trade, the law of trade, and the financing and resolution of disputes, have gone through considerable experimentation and are being improved and developed to meet constantly changing conditions and new needs of the economic cooperation between the socialist and market economies.

In the long line of trade agreements, the American model of 1972 contains the latest devices to promote the expansion of trade and to assure the success and security of transactions made between private exporters and importers and their Soviet counterparts. In contrast to earlier types of trade agreements, the U.S.-U.S.S.R. Agreement of 1972 relies upon a trade mechanism which is directly modelled on the SovietFrench arrangements. It consists of three elements:

a) U.S.-U.S.S.R. Commercial Commission;

b) Soviet Trade Representation in Washington and its counterpart U.S. Commercial Office in Moscow; and

c) Trade Organizations which make contracts and handle commercial transactions.

\section{A. U.S.Soviet Commercial Commission}

The creation of the Joint U.S.U.S.S.R. Commercial Commission was announced in the communique issued on the occasion of President Nixon's visit in Moscow on May 26, $1972 .^{7}$ According to the White House fact sheet issued at the press con-

\footnotetext{
${ }^{7} 67$ Bull. 898. Cf. G. Wilczynski, The Economics of EAst West Trade 75-im6 (I969). See also K. Grzybowski, The Socialist Commonwenlth of Nations 29 ff. (I964).
} 
ference held in the State Department on October I8, 1972, the Commission consists of the delegations of the U.S. and the U.S.S.R., headed by the Secretary of Commerce and the Minister of Foreign Trade, respectively. ${ }^{8}$

On two previous occasions the Soviet Union has used a Mixed (or Joint) Commercial Commission to manage foreign trade operations with a free economy country. A Trade and Navigation Agreement with Italy (March 5, 1947) provided for such a Commission which was to plan and control the trade between the two countries. The situation was somewhat unusual, because the Soviet Union was in the position of a creditor who could demand deliveries as a form of war reparations. While the Commission was oreated, the trade agreement did not provide for the establishment of the usual Trade Representation in Rome, and according to the original plan the duties of the Representation were to be the responsibility of the Trade Commission. Very little is known about the operation of the Commission, and apparently it could not accomplish what it was supposed to achieve, because on December II, I948, it was abolished and a regular Trade Representation in Italy was put in its place.

The idea of the Joint Commission was revived in French-Soviet relations but with a different task to perform. The Soviet Union and France had an earlier treaty on trade relations (September 3, 1953) which provided for the creation of the Trade Representation accredited in France. On June 30, 1966, the two countries decided in a joint declaration to establish a Joint Soviet-French Trade Commission in order to strengthen their economic, scientific, and technical cooperation. In $197 \mathrm{r}$ came another agreement which spelled out the functions of the Mixed Commission in greater detail. ${ }^{10}$

Under the U.S.U.S.S.R. agreement, the Commission has been charged with both specific and general responsibilities. Its specific responsibilities are the negotiation of the original trade agreement and its renegotiation for the period following the three years for which it was concluded. It also has to organize government credit facilities to finance commercial transactions, business facilities for the foreign trade firms, and arbitration mechanisms for the settlement of disputes arising in the course of trade. Further, the Commission is authorized to study possible investment openings for the development of resources and the manufacture and sale of raw materials and other products and, in general, to monitor the active spectrum of U.S.-U.S.S.R. commercial relations, identifying issues of interest for both parties, particularly patents and licensing. ${ }^{11}$

\footnotetext{
${ }^{8} 67$ BurI. 595.

13 S.D.D. U.S.S.R. 333 (Ministry of Foreign Affairs of the Soviet Union, Collection of Treaties and Agreements).

${ }^{10}$ I972 VNeshiniais Torgovis No. 2, at 6r-62.

${ }^{12}$ See note 7, supra. White House Fact Sheet (Bult., Nov. 20, 1972, at 593) states briefly that "[c]ach government agreed to make available to the other, on a reciprocal basis, trade credit arrangements which are usual and customary in the financing of exports. American credits will be handled by the Export Import Bank. Soviet credit shall be handled by the Vneshtorg Bank and through the credit facilities of more than forty trade associations."
} 
In contrast, the Soviet-French Agreement of October 27, I97I assigns a more concrete role to the Mixed Commission primarily within the context of the I970-1974 economic cooperation plans. The Agreement of I97x lists the following areas where France and the Soviet Union shall cooperate in order to promote their expansion and development: motor transport and tractors, tool industry, shipbuilding, electrical energy, computers, communications, black metallurgy, oil refining, gas, coal mining, ore mining, lumber, chemical and light industries. Problems of water and generally all areas which reveal possibilities of favorable development within the available means and resources shall receive special attention. Cooperation is to be achieved through a system of contracts in which French and Soviet industrial organizations will participate in joint projects, including modernization of the industrial establishments and, in particular, development of light industries producing goods for mass consumption. The concrete task assigned to the Mixed Commission seems to be the elaboration of the ten year program for the coordination of cooperation of the enterprises of both parties, not only in the Soviet Union and France but also in third countries. ${ }^{12}$

It appears that the Soviet-American Joint Commercial Commission closely resembles the French model. The greater precision of the 197r Soviet-French Agreement concerning the Commission's duties and functions seems to be the result of greater experience in the institutionalized economic cooperation between the two countries and to be influenced by the fact that both countries operate on the principle of economic plans. These plans, though substantially different in concept and execution, permit a more detailed and intimate planning of trade and assignment of mutual roles in the process of multi-sided economic cooperation. While-as it seems at this moment-planning and assignment of roles in the program of economic cooperation is possible in France, its role must be greatly restricted in the United States, where the role of the government is limited to promoting cooperation by removing the obstacles to trade. Concrete roles and responsibilities of American firms in SovietAmerican economic cooperation must result exclusively from contracts between Soviet and American business organizations. They can be assisted by the U.S. government within its powers (credit guarantees, import and export licenses), but they cannot be a matter of governmental plan. This is the meaning which is clearly conveyed by the provisions of article 2 of the Trade Agreement which in point 3 states:

Both Governments, by mutual agreement, will examine various fields, in which the expansion of commercial and industrial cooperation is desirable, with regard for, in particular, the long-term requirements and resources of each country in raw materials, equipment and technology and, on the basis of such examination, will promote cooperation between the interested organizations and enterprises of the two countries with a view toward the realization of projects for the development of natural resources and projects in manufacturing industries.

\footnotetext{
${ }^{12}$ See note ro, supra.
} 
B. The Soviet Trade Representation and the Foreign Trade Organizations

The technique of concluding foreign trade transactions in the Soviet Union calls for an allocation of roles between the two types of organizations which represent Soviet economic interests, the Soviet Trade Representation and the foreign trade organizations. Relations with American traders are the responsibility of the so-called Soviet foreign trade organizations which will effect commercial transactions on the basis of contracts to be concluded with natural and legal persons of the United States of America (article 2, point 2, of the Agreement). In addition, the parties have agreed to establish missions concerned with foreign trade, the Soviet Trade Representation in the U.S. and the American Commercial Office in the Soviet Union. They will have the status of diplomatic missions, and their members, the status of members of the diplomatic corps. Their employees and technical personnel, who are not nationals of the receiving country, will enjoy the status of members of the Soviet or American embassies, respectively. The responsibilities and duties of the two missions are dissimilar in some respects. While both missions are established in order to promote the development of trade and economic relations between the two countries and to assist their nationals in making contracts with their counterparts in the other country, only the Soviet Trade Representation has the power to "represent the interests of the Union of Soviet Socialist Republics in all matters relating to foreign trade ... with the United States. ..."13 However, the presence of the Commercial Office or of the Trade Representation in no way affects the right of the American and Soviet business circles to "maintain direct relations with each other with a view to the negotiation, execution and fulfillment of trade transactions" (article 5, point 3). Strengthening this clause is the proviso that those who will negotiate specific contracts cannot be members of the mission; neither can members of the mission participate directly under any circumstances in negotiating such contracts (article 6 , point 3).

Phraseology describing the functions of the Soviet Trade Representation and the U.S. Commercial Office clearly indicates a basic difference in their position in the social and economic organization of the two partners. The Trade Representation is able to represent the trade and economic interests of the Soviet Ministry of Foreign Trade which is the monopolistic manager of the external economic interests of the Soviet Union. Equality of Soviet and American partners in the trade between the two countries is more visual than real. American businessmen will not deal with Soviet foreign trade bureaucrats at the level of the diplomatic mission, but at the lower level of foreign trade organizations. However, while in the Soviet scheme of things this may not be important, the U.S. Commercial Office will be able to discharge its functions without being forced to represent the interests of a single firm, industrial group, or economic activity.

The provisions of the 1972 U.S.-U.S.S.R. Trade Agreement represent a considerable departure from the Soviet foreign trade regulations currently in force and the prac-

\footnotetext{
${ }^{13} 67$ Bull. 599. Cf. WilczYNSKi, supra note 7 at $75 f$.
} 
tices generally followed in Soviet trade with free economy countries. Legislation in the field of foreign trade and administrative control of foreign commerce is primarily within the jurisdiction of the federal authorities. The body of legal regulation pertaining to foreign trade consists of a number of acts. Among these are the provisions of the Constitution of the Soviet Union ( $193^{6}$ ) on the monopoly of foreign trade (article II) and the exclusive jurisdiction of the federal authorities in this matter (article 14). Also relevant in this connection is the Law on the Creation of the People's Commissariat of Foreign Trade, of November $15,1928,{ }^{14}$ as well as the Law on the State Committee of the Councils of Ministers of the Soviet Union for Foreign Economic Relations, of March 27, $1959,{ }^{15}$ and a Law on the Soviet Trade Representations and Trade Agencies Abroad, of September 13 , I933. ${ }^{16}$ Of the regulations made by the executive branch of the Soviet federal government, the most important is the Decision of the Government of the Soviet Union of March 27, I936, concerning the merging, establishment, division, and liquidation of trusts and other governmental organizations, and their separation from the organization of individual enterprises. ${ }^{17}$

In principle, government monopoly of foreign trade in the Soviet Union is handled by two types of government agencies. Soviet Trade Representations have the capacity to perform trade and business operations in the name of the Soviet Union, and thus directly to obligate, and to create rights and duties for, the treasury of the Soviet State. In addition, foreign trade organizations engage in foreign trade operations exclusively on their own account and create rights and obligations for themselves alone.

The overall supervision and the basic decisions in the matter of foreign trade policy belong to the Council of Ministers, which, among its other powers, has exclusive jurisdiction in the creation of foreign trade organizations and the determination of their responsibilities. Direct responsibility for the supervision, regulation, and control of foreign trade operations lies with the Ministry of Foreign Trade. The conduct of foreign trade operations is directly entrusted to foreign trade organizations. Foreign trade organizations stand in direct subordination to the Ministry of Foreign Trade. They are all-union juristic persons and, on instructions of the Council of Ministers, they are created by the Ministry. The Ministry determines the scope of their statutory activity, issues their charters, and publishes these in its official journal. Thus, their activity is planned, controlled, and supervised by the Ministry which appoints and relieves their officers and exercises disciplinary powers over their activities. The transactional activity of the foreign trade organizations, which was reshaped by the order of the Commissariat of Foreign Trade of February 28, 1930, is supervised and controlled by the Soviet Trade Representations accredited abroad, according to their territorial competence:

\footnotetext{
${ }^{14}$ Soviet Laws 1928, No. ro, at 302.

${ }^{25}$ Pravovole Regulartvanie vNeshnei torgovli 9, 42 (D. Genkin ed. I96I).

${ }^{10}$ Soviet Laws I933, No. 59, text no. 354.

${ }^{17}$ Soviet LAws 1933, No. I8, text no. I5I. See also Wilczynski, supra note 7 , at 78 f.
} 
Representatives of the Ministry of Foreign Trade regulate and supervise commercial activities ... of the trade organizations of the U.S.S.R. permitted to participate in foreign trade operations.

This mechanism for the management of imports and exports, as well as other aspects of economic cooperation with the free economy countries, was the result of considerable experimentation and historical development. After the Revolution (I9I7), when all private enterprise was taken over by the government, it was necessary to create special channels for commercial cooperation with the capitalist countries.

From the beginning, it was the constant policy of the Soviet government to maintain in each country a special agency with diplomatic status in charge of the economic aspects of Soviet foreign relations. However, as this was an innovation in diplomatic practice, the creation of such institutions was possible only with the approval of the countries of accreditation-approval given at the price of certain concessions with regard to the diplomatic immunities of the trade missions. The general practice followed in Western Europe, which set the pattern for similar situations elsewhere and is followed today, was that whenever a trade mission was actually in charge of trade operations and had entered into contracts with foreign business circles, it would not enjoy exemption from local jurisdiction as regards litigation arising from such contracts. ${ }^{18}$ Accordingly, the international treaties entered into by the U.S.S.R. with non-communist countries set up conditions for the operation of the Soviet Trade Representations abroad. They submitted Soviet foreign trade transactions to the rule of foreign law and established the venue of foreign courts to hear and decide litigation arising from such transactions.

A good deal of experimentation was also needed to reach the current form of the foreign trade organizations representing the interests of the various branches of Soviet industrial activity. Foreign trade representations, as they are now called, have been active under various names (e.g., Export Import Stock Companies). At all times, however, the most important aspect of their status has been their legal and organizational separation from the official bodies in charge of the government's monopoly of foreign trade. On June 22, I927, the Central Executive Committee and the Council of People's Commissars of the U.S.S.R.'s decree on firms caused foreign trade representations to use distinctive names in foreign trade operations. ${ }^{10}$ They are created and established by the decision of the Council of Ministers of the U.S.S.R. The Minister of Foreign Trade enacts a charter of the new association and appoints and dismisses its officers. Statutes and the names of officers, as well as the names of those who have the right to sign commercial transactions and assume obligations in the name of the association, are published in the official journal of the Ministry of Foreign Trade. Foreign trade organizations are terminated, on proposal of the Minister of Foreign Trade, by the Council of Ministers of the U.S.S.R. ${ }^{20}$

\footnotetext{
${ }^{18}$ K. Grzybowski, Soviet Private International Law 160-6i (1965).

${ }^{10}$ Soviet Laws I927, No. 40, text no. 394 .

${ }^{20}$ Genkin, stupra note 15 , at $44-45$. Winding up and reorganization of foreign trade organizations is
} 
While it is clear that foreign trade organizations are governmental agencies and that their activity is an exercise of governmental power established by the monopoly of foreign trade, the organizations enjoy the status of separate legal entities, and have assets assigned to them for the purpose of achieving their specific tasks. For the purpose of execution, these assets are not part of the Soviet exchequer. ${ }^{21}$

Throughout the entire history of Soviet trade relations with foreign countries, both trade delegations and foreign trade organizations have had a role to play. For a time, trade delegations were the main agency entering into contracts; since 1935, foreign trade organizations have assumed the responsibility for actual trade operations, with the trade delegations performing supervisory and regulatory functions.

In the early period, when the main technique of Soviet foreign trade was barter agreements, consisting of exchanges of commodities for commodities, trade relations were so simple that no important legal issues could arise in the course of such transactions. ${ }^{22}$ In the ensuing period, which lasted until the early thirties, all contracts were made by Soviet foreign trade delegations. During that period, contracts were concluded abroad, and unless the parties to such contracts had agreed otherwise, all litigation which resulted from trade relations was subject to foreign law, foreign arbitration, or foreign courts. In other words, in the first ten years of the regime of the foreign trade monopoly, the laws which governed Soviet trade relations with other countries were the provisions of trade treaties or foreign private international law.

In the early thirties, Soviet Trade Representations began to experiment with contracts, which provided for the jurisdiction of Soviet arbitration commissions and for the application of Soviet private international law, to determine the material law governing a specific trade transaction. Finally, in 1935 the technique of foreign trade was thoroughly changed. Trade delegations were assigned controlling and supervisory functions, given administrative responsibility for issuing import and export licenses, and relieved of conducting foreign trade operations. This task was assigned to the foreign trade organizations seated in Moscow. Unless contracts and agreements between parties provided otherwise, Soviet arbitration organizations became the forum and Soviet private international law the proper law for Soviet trade transactions. This also meant that the emphasis was switched from foreign law and the law of the treaties to Soviet internal legislation and the decisions of Soviet arbitration organizations which could now develop in their practice a body of Soviet private international law.

The decision not to accord Soviet Trade Representations a right to make contracts has important consequences. In terms of international law, a Soviet Trade Representation is a diplomatic mission and a part of the Soviet Embassy in Washington,

effected on the basis of the decree of the Central Executive Committee and the Council of People's Commissars (today the Council of Ministers). Cf. Soviet Laws 1936, No. 18 , text no. I5I.

21 See GrzYBowski, supra note I8, at 44-45; Genkin, supra note I5, at 44-47.

${ }^{22}$ Korolenko, Torgovye soglashenia SSSR $s$ innostrannymi gosudartvami (Soviet trade agrcements with foreign countries) $16-17$ ( 1963$)$. 
with a traditional diplomatic status. There is no Soviet commercial arm present in the United States which can make (on a regular basis) contracts with American exporters to which the Soviet Union is a party. The explanation of American reluctance is justified by the fact that the American legal system makes it impossible for the American government to make this concession. The letter of the Secretary of Commerce addressed to the Minister of Foreign Trade of the Soviet Union makes it clear that Title 22 of the U.S. Code, sections 252-254, makes it inappropriate for the Trade Representation and its staff to participate directly in the negotiation, execution, or fulfillment of trade transactions or otherwise carry out trade. Should, however, America become a party to the Vienna Convention on Diplomatic Relations of $\mathrm{rg}$. I and the legislation in force be properly amended, the United States is prepared to renegotiate the terms of the Trade Agreement, in the sense that the Trade Representation be able to discharge the obligations entrusted to it under Soviet legislation of making certain classes of transactions and contracts in addition to those made by the foreign trade associations. In such a case the provisions of the Trade Agreement will have to be properly amended to define the responsibility of the Trade Representation and of the Soviet Union for contracts made with American firms and the extent to which they are responsible for assets the Representation controls for its obligations incurred in the United States.

III

\section{Legal Regime of Soviet-American Trade}

The Trade Agreement outlines only the general conditions of the commercial activities of Soviet and American economic organizations in the foreign trade between the two countries. Its rules are rules of international law, and their status depends ultimately upon the provisions of the American Constitution and Soviet internal law. In this category belong provisions dealing with the most-favored-nation clause and its limitations, the status of the U.S. Commercial Office in the Soviet Union and of the Trade Representation in the United States, and rights directly guaranteed to American traders in the Soviet Union and Soviet foreign trade organizations in the United States. On occasion the Agreement refers to the laws and regulations current in both countries as providing the legal framework of governmental cooperation in promoting trade between the two countries and of the commercial transactions effected by Soviet and American firms. ${ }^{23}$ The Agreement also accepts as competent the law of each party to determine the status of their legal persons.

\section{A. International Law of Soviet-American Trade}

\section{Most-Favored-Nation Clause}

The concept of the most-favored-nation clause was devised to frustrate discrimination between goods of different origins competing in essentially free markets, by

\footnotetext{
${ }^{23}$ Article 2, point 2, and article 6 refer to "regulations then current in their countries."
} 
assuring equal treatment as regards customs, taxation, and cost of transport, inasmuch as these things are controlled by the government of the country. The most-favorednation clause presumes an even level of government controls in the partner countries, so that imports from countries covered by the clause have a fair chance to compete. In other words, for its operation a most-favored-nation clause in its original role depends upon the existence of the market.

Operation of the most-favored-nation clause in economic relations between free and planned economies is not a simple matter. The clause works differently in a planned economy country, where imports and exports are controlled by the economy which determines types, assortment, origin, and distribution of goods, thus, in practice eliminating the element of competition. The key factor in the operation of the most-favored-nation clause is the extent of control of the economic processes by the public authority. It is less extensive in the United States than in the Soviet Union; article I of the Trade Agreement must be read with this in mind.

The most-favored-nation clause in American-Soviet trade includes (a) customs duties and other charges, (b) internal taxation, sale, distribution, storage, and use, (c) charges upon the international transfer of payments for importation or exportation, and (d) rules and formalities in connection with importation and exportation. It is clear that in the United States government control over these matters is less pervasive than in the Soviet Union. While the Soviet government is able to control the sale, distribution, storage, and use of the American goods imported in the Soviet Union, these same aspects of trade operations are the responsibility, in the United States, of American buyers and importers. The American government is unable to prescribe methods for storing, use, sale, or distribution of Soviet commodities, except for reasons of public safety.

Although technically bilateral, point 2 of article I must be read as, in fact, a unilateral reservation. It states:

In the event either Government applies quantitative restrictions to products originating in or exported to third countries, it shall afford to like products originating in or exported to the other country equitable treatment vis-à-vis that applied in respect of such third countries.

This provision seeks to assure fair treatment of Soviet exports to the U.S. or American exports to the Soviet Union in case either country should decide to limit imports or exports of certain commodities for internal economic reasons. It must be pointed out, however, that in the Soviet Union, imports are planned, and quotas are a part of the entire system of trade operations, which tends to balance imports with exports, while on the U.S. markets quotas have only a limited application.

The most-favored-nation clause is inoperative as regards privileges extended to other countries under multilateral trade agreements (such as GATT or Council for Mutual Economic Assistance) and special relations existing because of the territorial neighborhood. Furthermore, it cannot frustrate privileges granted under the resolution adopted by the rg68 United Nations Conference on Trade and Development to 
developing countries. In addition to these restrictions which are designed to prevent the exploitation of the market of one of the parties for purposes which are contrary to the idea of orderly economic cooperation, the Agreement includes provisions intended to protect the internal balance of the market (article 3) and the national security of each country (article 8 ).

Article 3 gives each party the power to take steps to ensure that imports from the other country do not cause, threaten, or contribute to the disruption of its domestic market. Article 8 provides that each party has the right to take steps to safeguard its security interests. Article 3 is couched in general terms. Its form suggests that both governments desired to reserve the greatest freedom of action, and it would be a fair interpretation of article 3 to say that the threat to national security need not necessarily originate in foreign trade transactions between the U.S. and the Soviet Union. It may be a consequence of a disruption on a world market, which would force either government to take preventive action affecting trade with the other country. One may presume that in that case the fair treatment clause of article I (point 2) would apply.

The anti-dumping provisions of article 3 of the Agreement are amplified in Annex r of the Agreement. It provides for a consultation between the parties for the exchange of views and resolution of the problem by an agreed action. In case of emergency (of which each party is ultimately the judge) preventive measures may be adopted unilaterally even before arriving at an agreed solution. Should the parties fail to agree, the party which thinks its economic position is endangered will make the decision, which will be considered as arrived at with the agreement of the other party.

The anti-dumping provisions are designed to protect the American economy against an aggressive Soviet export policy. Foreign trade operations in the Soviet Union are a matter of a plan distributing exports and imports in general, in which the initiative for raising or lowering the volume of imports or exports belongs to the Soviet government which has the foreign trade monopoly. Methods by which the Americans may normally control the volume of the trade are licensing and credits, powerful instruments indeed-powerless, however, in the case of a determined export policy of the Soviet partner. ${ }^{24}$

\footnotetext{
2"In the inter-war years the Soviet Union was accused of dumping, chiefly grain; this secms to have been due to the policy of forced exports in order to finance Sovict industrial expansion and to pay for large orders of machinery and industrial plants abroad. There is little likelihood that the Soviet Union will resort again to this policy. It is chronically short of the grain necessary to meet its internal needs, and Soviet consumer goods are not only in short supply but also unattractive to the Western public. At the same time, it is interesting to note that the anti-dumping clause of article 3 defines no objective criteria to determine when dumping occurs.

When confronted with the history of dumping it is clear that the economic regime in the Soviet Union, which depends on government monopoly of industrial production, distribution, and forcign trade, represents an ideal set of conditions permitting systematic dumping. See Viner, Dumping, 3 ENcYcLopediA of Social Sciences 275 (I935). See also S. Metzger, I Law of Internationat Trade: Documents and Readings 730 ff. 745 ff. (rg66). Article VI of the General Agreement on Tariffs and Trade uses the criterion of "sale at less than normal value."
} 


\section{Soviet-American Trade Business Community}

On four occasions the Trade Agreement refers to the circle of persons and economic organizations which may participate in Soviet-American trade. Article 2 (point 2) twice refers to natural and legal persons of the United States and foreign trade organizations of the Soviet Union. Article 5 assures that this business community will not be circumscribed in its rights to maintain direct relations with each other by the fact that each country concerned shall have a Commercial Office (U.S. in the Soviet Union) or a Trade Representation (Soviet Union in the U.S.). Article 6 assures that this circle of persons representing the economic interests of the two countries shall have the right to open their representations in the other country. Article 6 (point 3) of the Agreement states that:

Corporations, stock companies and other industrial and financial commercial organizations, including foreign trade organizations, domiciled and regularly organized in conformity to the laws in force in one of the two countries shall be recognized as having a legal existence in the other country.

Finally, article 7 of the Agreement provides that each government shall ensure that corporations, stock companies, and other industrial or financial commercial organizations, domiciled and regularly organized in conformity to the laws in force in the other country will have the right to appear before the courts of the former.

There is no problem in identifying the Soviet legal entities entitled to participate in the U.S.Soviet trade. They are the foreign trade organizations listed in the Official Journal of the Ministry of Foreign Trade and are a part of the Soviet government. Their status within the Soviet-US. trade community is equal to that of the American natural and legal persons. Their exclusive right to represent Soviet commercial interests with the United States is confirmed in the letter of the Soviet Minister of Foreign Trade, stating the restriction that offices of American firms in the Soviet Union may communicate with Soviet organizations that do not have the right to operate in foreign trade only through the Ministry of Foreign Trade. ${ }^{25}$

The membership of Americans in the Soviet-American trade community relies on two criteria: formal nationality of the natural persons (American only), and incorporation and domicile as regards legal persons. The general effect of these provisions is that the Trade Agreement incorporates into the legal regime of the SovietAmerican trade the lex patriae of the members of its community.

Provisions of the U.S.Soviet Trade Agreement conform to Soviet trade agreements with other countries by stressing real connections with a given country for the determination of the corporate nationality. While Soviet civil legislation is silent in the matter of the factors determining the nationality of a foreign juristic person, trade and navigation agreements follow a fairly uniform line and establish in Soviet treaty practice the usual criteria of nationality.

Two elements are used to determine the nationality of foreign (capitalist or Soviet)

\footnotetext{
${ }^{25} 67$ Bell. 601-02.
} 
firms or corporations: factual connection with the territory of a given country and the legal context of the corporation's creation. So, for instance, a Soviet-Canadian Trade Agreement of February 29, 1956, refers to:

Soviet citizens and Soviet economic organizations and other juristic persons established according to Soviet laws on the one hand, and Canadian citizens and other physical persons living and conducting business activities in the territory of the other ....26

The treaty with France (September 3, I953) speaks of juristic persons established according to French laws and of Soviet juristric persons, which have, according to Soviet legislation, civil capacity. The treaty mentions French merchants and industrialists, and also Soviet state organizations which enjoy under Soviet legislation the rights of independent juristic persons. ${ }^{27}$ The trade agreement with Switzerland (March I7, I948) speaks of juristic persons and trade enterprises established in the territory of the contracting parties in accordance with the legislation in force in that territory. ${ }^{28}$ The treaty with Turkey (October $8,{ }^{1937)}{ }^{29}$ is more specific. It grants the status of a juristic person and the right to appear in courts both in the capacity of claimant and respondent to organizations established under the laws of one country for the purpose of trade and industry in the territory of the other. In some cases, the nationality of juristic persons and foreign trade associations is determined by reference to the seat of a given economic institution in the territory of one of the contracting parties. ${ }^{30}$

Treaties with the socialist countries simply omit reference to criteria of nationality, as nationality is beyond question in this context. ${ }^{31}$ This is easily explained by the fact that the organization of the foreign trade mechanism in the socialist countries follows the Soviet pattern. The number of foreign trade concerns involved is limited, and they are governmental organizations assigned to handle foreign trade operations. On the whole, however, Soviet treaty provisions seek to establish the connection of foreign firms or corporations with the territory of the treaty-partner. Therefore, the emphasis is on where the company or merchant or industrial concern has its seat or is incorporated, or both, the salient factor being the country to which a person or economic organization is legally connected by economic activity.

Incorporation in Soviet law is an act of authority bestowing legal capacity on a governmental organization. It is also an act assigning tasks and responsibilities in the economic life of the country and providing financial means and economic assets to fulfill its function. Incorporation in Soviet practice is the control principle in a social

\footnotetext{
${ }^{23}$ Sovier Laws 1956, No. 13, text no. 464 .

${ }^{27}{ }_{15}$ S.D.D. U.S.S.R. 48.

${ }^{28}$ I3 S.D.D. U.S.S.R 263.

29 xo S.D.D. U.S.S.R. 78.

${ }^{30}$ Agreements with Austria, October I7, I955, I7-I8 S.D.D. U.S.S.R. 280; with Albania, September 27, 1957, 20 S.D.D. U.S.S.R. 462; with Yugoslavia, May 10, 1940, 10 S.D.D. U.S.S.R. 94; with Poland, July 7, I945, I2 S.D.D. U.S.S.R. 97.

${ }^{31}$ I3 S.D.D. U.S.S.R. 352.
} 
order in which the ownership of all means of production is vested in the state, and the organizing functions in the economic life of the country are the monopoly of the government. $^{32}$

Soviet writers insist that Soviet private international law relies on the incorporation principle in determining the nationality of a juristic entity. While this seems an adequate criterion in the Soviet Union, in the free economy countries the incorporation principle is far from satisfactory. This is reflected in Soviet treaty practice which usually supports the incorporation criterion with an additional element indicating a real link with a national territory and its economic life. ${ }^{33}$

\section{International Commercial Practice}

In addition to the rules of national law which govern contracts between the partners in the U.S.-U.S.S.R. trade, article 2 (point 2) provides that contracts in SovietAmerican exchanges shall be "generally concluded on the terms customary in international commercial practice." This includes not only commonly used commercial terms such as C.I.F, F.O.B., or C.O.D., but also those aspects of trade transactions concerning performance, delivery, payments, evidence of faulty delivery or shortages which are not mandatorily regulated by the legislation of either of the two countries, the United States or the Soviet Union. In terms of commercial customs, U.S.-U.S.S.R. trade has become a part of the general international movement of goods. ${ }^{34}$

\section{B. Soviet Law of Foreign Trade}

\section{Legal Capacity of Soviet Foreign Trade Organizations}

Transactions and contracts of foreign trade organizations are exempt from the general provisions of civil law but are subject as to their form to the rule of Soviet law governing foreign trade transactions, irrespective of the place where such transactions or contracts are made. According to article 125, paragraph 2, of the Principles of Civil Legislation of Ig6r:

The form of foreign trade transactions entered into by Soviet organizations and the method of their signature are laid down by the legislation of the U.S.S.R. irrespective of the place of the transaction.

Soviet civil law contains only general provisions concerning the scope of the legal capacity of Soviet juristic persons. ${ }^{35}$ In each case in which a legal entity is created, its rights and powers are described in its charter in accordance with its specific functions in the Soviet economy. Its organization is a reflection of the dependence of Soviet legal entities upon the higher administrative authorities and its subordination to the economic policies formulated by the government.

Accordingly, Soviet scholars point out that Soviet legal entities are subject to

\footnotetext{
${ }^{32}$ L. Lunts, 2 Mezhdunarodnoe Chastnoe Pravo i6i-62 ( 1963 ).

${ }^{83} I d$.

is GrzYBowski, supra note I8, at 58-60.

${ }^{35}$ Cf. Principles of Civil Legislation of $196 \mathrm{I}$, art. II; R.S.F.S.R. Civil Code, art. 26.
} 
specific regulations and are endowed with a so-called special legal capacity. This is also true of the foreign trade organizations. Federal regulations determine all aspects of their organization and activity including

the scope of the legal personality of the foreign trade organizations as governmental economic juristic persons; the special legal capacity of the organization and its limits; the separate property status of the trading organization and its legal responsibility; the relations of the organization with the Ministry of Foreign Trade of the U.S.S.R. and with other foreign trade agencies of the government; the exercise of legal powers of the organization; representation and form of contracts; property subject to execution. ${ }^{36}$

In practical terms the special legal capacity of the foreign trade organizations is determined by the so-called "nomenclature" (official description) of the group of commodities which is covered by the foreign trade activity of that particular trade organization. Each foreign trade enterprise must limit its activity to that particular line of products for which it was created, and it is illegal for it to conclude foreign contracts either for the export or import of items not included in the classes of goods which it is entitled to sell or to buy. ${ }^{37}$

The trade mechanism of the Soviet Union is primarily oriented towards economic cooperation with the free economy countries. However, inasmuch as foreign trade with the socialist countries consists of the normal exchange of goods, the same network of authorities also handles that aspect of the international commerce of the Soviet Union.

Although foreign trade organizations are endowed with special legal capacity and are organized in order to fit their specialized tasks, they share certain charactteristics, some of which are limited exclusively to their circle, and some of which are common to all legal entities of the Soviet Union. They have the right to issue and receive promissory notes although this type of negotiable instrument is not permitted to circulate within the Soviet Union.

A feature which foreign trade organizations share with other Soviet legal entities and government organizations acting on the business accounting principle (khozraschet) is that they are responsible for their debts and obligations only to the extent of their assets. Ownership of assets and the means by which Soviet foreign trade organizations meet their financial obligations are determined by the provisions of the civil law. According to section 13 of the Principles of Civil Legislation of $\mathrm{r} g 6 \mathrm{x}$ :

A juridical person is liable for its obligations to the extent of its property (or if a State body with legal personality, to the extent of the property allotted to it) so far as such property may be taken in execution of judgment under the legislation of the U.S.S.R. and the Union Republics. The State is not liable on the obligations of State

\footnotetext{
${ }^{86}$ Genkin, Legal Status of Soviet Export and Import Organizations Abroad, ProblemiY MEzhduNArodnogo Chastnogo Prava 7-8 (ig6o).

${ }^{37}$ Genkin, supra note 15 , at 47.
} 
bodies which have legal personality, neither are these organizations liable on the obligations of the State ....

In practice this results in a considerable restriction of the assets which are available to satisfy the claims of foreign creditors. The liability of foreign trade enterprises extends only to sums of money, commodities in their possession, and claims on other persons or organizations. Claims against the foreign trade organizations cannot be satisfied from fixed assets and capital equipment in their ownership. In practice, however, foreign trade organizations have little or no fixed assets or capital equipment. Their statutes always provide that they are established with a fixed sum or capital which represents credit opened for such associations in a governmental bank, and as such may serve as the means for satisfaction of claims advanced by their creditors. ${ }^{38}$

So long as satisfaction of the claims of foreign creditors is sought from the assets situated in the Soviet territory, execution has to comply with those provisions which restrict the means for satisfaction. It is a part of Soviet public order that certain assets are extra commercium, and are not transferable in the process of execution. The situation may, however, be different with respect to assets situated abroad. Under the terms of a trade agreement, the position of Soviet trade organizations abroad is determined by reference to rights which they enjoy under the foreign law. So, for instance, according to article i2 of the trade agreement with Japan of I958:

Soviet citizens and Soviet economic organizations and other juristic persons created according to Soviet laws, shall enjoy in accordance with the law in force, as regards the protection of their persons and property, such a regime as is granted to citizens and juristic persons of any other state, while engaged either directly, or through representatives of their own choice in economic activity on the territory of Japan, as this activity is under the rule of Japanese legislation in force.

Article 3 of the Annex to the same treaty regarding the legal position of the Soviet trade delegation in Japan states that:

It is understood that any contracts entered into without the guarantee of the Trade Delegation by any of the Soviet organizations, which according to the Soviet legislation enjoy the status of independent juristic persons, create obligations only for those organizations, and execution on the basis of those contracts can be directed only against their property. Neither the Government of the Soviet Union, nor the Trade Delegation, and any other Soviet organizations, with the exception of those which are parties to the contract, bear any responsibility as regards those contracts.

As a matter of course Soviet trade agreements contain restrictions on the means which may serve to satisfy claims resulting from contracts concluded by, or with the participation of, the Trade Representation of the Soviet Union. Some of the treaties expressly specify that execution may apply to goods, sums of money, or claims

${ }^{38}$ Id. at $52-53$. 
which constitute the property of the Soviet Trade Representation. In some instances (for example, in the agreement with Greece of June Ir, I929) execution on assets which are the property of the Soviet Union is excluded since the Soviet Union guarantees the payment of the obligations assumed by the Soviet Representation. Sometimes, and this is the most frequent form, execution is permitted against all assets constituting the property of the Soviet Union abroad, excluding that property which serves purposes connected with the sovereign status of the Soviet State. To this latter category belong buildings or objects used in order to maintain a diplomatic representation, ships of the U.S.S.R. Navy, and other governmental ships.

The question arises as to the position of Soviet law regarding execution on fixed assets which are the property of a Soviet legal entity but which are situated abroad. Unless there is a provision in the trade agreement with the country of their location, execution on such assets would come under the rule of lex rei sitae. The question arises as to what extent the rights of foreign creditors are limited by those provisions which form the statutum personale of a Soviet foreign' trade representation. This is not a purely theoretical question. In Ig62 the Council of Ministers of the U.S.S.R., by the Order of August 22, $\mathrm{r} 962,{ }^{39}$ created the Foreign Trade Bank of the U.S.S.R. Its Charter gave the Vneshtorgbank, as it is called, the right to open branches and agencies both at home and abroad and to maintain representatives there. It was also empowered to acquire real property abroad. Under section 3 of its Charter, the Bank is liable for claims against it to the extent of that property which, according to the laws of the U.S.S.R., is subject to execution. This would exclude execution upon real property and other fixed assets.

One could argue that execution upon similar assets situated abroad would not be permissible. However, according to section 37 of the Charter, acquisition of real property abroad is subject to local law, which cannot be changed by Soviet legislation. It would seem therefore that, unless there are special provisions in international treaties limiting the right of foreign creditors in this respect, execution is permitted on fixed assets belonging to a Soviet juristic person and situated abroad. This reasoning is strengthened by the terms of the trade agreements, which provide that parties to the treaty accept the obligation to give effect to the arbitral decisions passed in the territory of one country according to the legislation of the lex fori. ${ }^{40}$

The rules which govern the activities of foreign trade organizations fall into two categories. They reflect the fact that they are government organizations in charge of a government monopoly, and also that, as legal entities, they have a separate civil law status. In the first category, foreign trade organizations are subject to economic plans and regulations issued in this connection. These include instruments and orders of higher administrative authorities responsible for the industrial province in which the trade organizations are active. They must follow regulations of the Ministry of Foreign Trade and its departments, issued in connection with the tasks assigned to

\footnotetext{
${ }^{80}$ I963 VNeshniata Torgovila No. 3.

${ }^{40} \mathrm{Cf}$. article ${ }_{5}$ of the Soviet-Yugoslav Trade Agreement of May II, I940.
} 
them. They must abide by changes in the economic plan for a given period made by competent governmental agencies. At the same time, foreign trade organizations must conform with the provisions of Soviet law governing the form and formalities of their transactional activity, the general rules of the Soviet civil law, and the rules of their creating statutes, particularly insofar as they determine legal capacity.

One of the important issues in this connection is the question as to which of these rules have extraterritorial effect and, thus, influence the validity of the foreign trade transactions and contracts concluded with a foreign trader abroad. There seems to be no doubt that the provisions of the charters of foreign trade enterprises and the foreign trade regulations, which determine the mode of conclusion of contracts as well as the legal capacity of Soviet foreign trade organizations, will effect the trade organizations' dealings with their partners abroad.

Another important issue is the extraterritorial effect of the economic planning acts in the context of their effect on the validity of contracts made by Soviet trade organizations with foreign partners. Under article 234 of the Civil Code of the R.S.F.S.R. of rg64, changes of economic plans may modify the obligations between the parties only when the decisions of the higher administrative authorities are obligatory for both parties. This clearly cannot apply to foreign trade transactions. Neither foreign firms of the free economy countries nor foreign trade agencies of other socialist countries are bound by the decisions of the Soviet administrative authorities. Thus, it seems that there is no rule in the Soviet civil law which would govern situations of this type. The only provision relating to this issue is to be found in the government decision of July 27, 1935, which gives the Ministry of Foreign Trade the right to cancel contracts concluded by a foreign trade enterprise with foreign firms. There seems to be, however, no doubt among Soviet scholars that decisions of this type lack extraterritorial effect and that they do not relieve a Soviet organization from contractual responsibility under the general rules of Soviet civil law. ${ }^{41}$

Yet another problem arising in connection with the special legal capacity of the foreign trade enterprise is the effect of ultra vires contracts on the rights of the foreign firms. The question of ultra vires contracts has broad meaning in the Soviet legal and economic order. A contract which clearly violates the scope of commercial activity, as determined by the Charter, is also contrary to the decisions of the economic plan and, in a sense, violates the public policy of the Soviet State. In the field of foreign trade, the structure of the foreign trade organizations reflects the assignment of economic tasks determined by the plan. The scope of specialized responsibility of the foreign trade organization is not only the result of the rule of civil law but also a consequence of the public order of the State.

The specialization principle is enforced by the provisions of the Civil Codes of the Union Republics, such as articles 48, 49, and 50 of the Civil Code of the R.S.F.S.R. of I 964 which provide for penal measures in addition to the declaration of the nullity of contracts made in violation of the tasks determined in the statutes.

\footnotetext{
${ }^{1}$ Genkin, supra note 36 .
} 
According to article 50 of the Civil Code of the R.S.F.S.R. of $x 964$, a contract is null and void if made in violation of the assignments determined in the statutes of a Soviet legal entity and contrary to the law dealing with that type of legal entity. According to article 48 of the same Code, in such a case the parties who have accepted delivery in whole or in part or have performed all or part of the contract must return what they have received or, if that is impossible, must pay an equivalent sum of money. Should such a contract be made with the willful aim of harming the interests of the State or of society, article 49 of the Code provides for penal sanctions by way of confiscation of anything acquired under the contract by the guilty party. These provisions of the Civil Code will have only a limited effect as regards foreign trade transactions. As Professor Genkin informs his readers, Soviet courts and governmental arbitrators avoid punishment by confiscation but are inclined to apply fines since these are considered a more effective punishment than confiscation. When, according to the circumstances, the application of punitive measures is not considered necessary, judicial authorities are satisfied with the restitution to each party of the goods delivered or payments made between the parties. However, it is Soviet policy that penal measures are never applied to the foreign party in a foreign trade transaction. ${ }^{42}$

Another problem of private international law arising in connection with the Soviet system of control over foreign trade operations is the question of the legal effect of the refusal of the governmental authorities to grant import or export licenses. Both the Ministry of Foreign Trade and the Soviet Trade Representation in' a given foreign country control the flow of trade by issuing import and export permits covering individual transactions and authorizing the delivery of goods. The licensing system has a special role in the Soviet Union. In spite of the fact that the export and import of goods is a matter of governmental decision, fluctuations in the execution of the plan force the government to adjust the planned tasks to the existing situation.

There are no rules in the Soviet legal system which directly deal with the matter. However, a highly authoritative manual, prepared under the auspices of the All Union Academy of Foreign Trade, expresses the view that refusal of the competent authority to issue a proper import or export license cancels the contract and relieves the parties from its fulfillment according to the general rules of the Soviet Civil Code.

The question remains, however, as to the consequences of a provision in the contract whereby the Soviet partner assumes the obligation to obtain the necessary permits. It is the considered opinion of the authors of the same manual that failure to obtain such a permit does not provide automatically a ground for claiming damages from the Soviet trading organization. Damages may be claimed only if the failure to obtain a permit was the fault of the Soviet partner due to his failure to take proper steps with the competent authorities. The authors of the manual point to articles II8 and II9 of the Civil Code of the R.S.F.S.R. of r922. Since the foreign trade manual was published, the provisions of the R.S.F.S.R. Code of the NEP

\footnotetext{
${ }^{42}$ Id. at I2.
} 
period have been replaced by the Civil Code of 1964 which contains the relevant provisions in articles 222 and 235. According to article 222:

The party who has not performed its obligation or who has performed it in an improper manner, is materially responsible only in case of fault (intent or negligence) except in cases provided for in the law or under the terms of the contracts. Absence of fault must be proved by the party in breach.

According to article 235, "[o]bligations are terminated by the impossibility of performance, if it was caused by circumstances for which the debtor is not responsible." The additional argument in support of this thesis is that Soviet foreign trade organizations, as legal entities separate from the State, are subject as regards their liabilities and obligations to the rule of the civil law only, since their activities have nothing in common with the exercise of governmental authority.

It is interesting to note that the Soviet authors of the manual fail to mention that the question of responsibility for failure to obtain an export license was reviewed by the Soviet Foreign Trade Arbitration Commission in the case of the Israeli Oil Arbitration and that the authors' thesis was upheld. This may suggest that the Soviet authors did not think it politic to underscore the additional hazards of trading with the Soviet Union. ${ }^{43}$

The matter has not yet been the subject of a judicial decision in a free court, and as such is far from settled. It is easy to see that a court of a free economy country will be concerned with the degree of identification of the trading organization with the official government of the Soviet State.

\section{The Law of the Contract}

Under article 126 of the Principles of Civil Legislation of rg6r, "the rights and duties of parties to a foreign trade transaction are defined by the laws of the place of the transaction, unless the parties agree otherwise. Soviet law decides in what place a transaction is effected." 44

Since the 1935 reform of the foreign trade procedures, the law governing foreign trade contracts has been brought into close connection with the Soviet legal system. Under the new regime, foreign trade organizations have become the main contractmaking agency, replacing the trade delegations acoredited in the capitals of foreign countries. In the new situation, the place where contracts are made is usually the seat of the foreign trade organization, which in all cases is Moscow. So, unless parties agree otherwise, the Code of the R.S.F.S.R. and Soviet federal legislation provide the law of the contract. Article 126 of the Principles of Civil Legislation must be read in conjunction with article I24, which permits foreign firms to make contracts in the Soviet Union, and with the provisions of the Civil Code of the R.S.F.S.R. of 1964 (articles I62-64), which deem the contract concluded at the moment when an answer to an offer is received by the offeror. ${ }^{45}$

\footnotetext{
${ }^{48}$ Id. at 41-42. Cf. Domke, The Soviet Israeli Oil Arbitration, 53 AM. J. INT'L L. 787 (I959).

"Cf. R.S.F.S.R. Civil Code of 1964 , art. 56 .

${ }^{4}$ Cf. R.S.F.S.R. Civil Code of I922, art. 135.
} 
Under current laws, Soviet public order combines exclusive governmental ownership of the means of production with the legal possibility of sale of such means of production to foreign traders transacted under the protection of the Soviet legal order. According to article 59 of the Principles of Civil Procedure of $\mathrm{x} 96 \mathrm{r}$,

foreign citizens have the right of access to Soviet courts and enjoy equal procedural rights with the Soviet citizens. Foreign enterprises and organizations have the right of access to Soviet courts and enjoy procedural rights for defense of their interests.

And yet, the peculiarity of the Soviet legal system is such that it is useless to look to the civil law of the Soviet Union or to the foreign trade regulations for a substantive rule which would validate foreign trade transactions. In the last analysis, the legality of foreign trade transactions rests on the charters of the foreign trade associations which give them the right to sell abroad a predetermined line of products of the Soviet industries.

At the present time foreign trade represents a reality of social and economic activity which is set apart from other areas of Soviet social and economic life. Although, as a rule, foreign capital is not admitted to economic activity in the Soviet Union, it participates in one form or another-such as trade credits-in promoting Soviet international commerce. ${ }^{46}$ Foreign firms, both physical persons and capitalist corporations, can acquire ownership of goods, including capital equipment, which are extra commercium for physical persons residing in the Soviet Union.

It is quite logical, therefore, that Soviet foreign trade relations live under a legal system of their own. The public law of this system does not insist that Soviet property relations be given extraterritorial effect. Private property rights conceived as capitalist ownership of the means of production are enforceable in Soviet courts. The form of contracts and foreign trade transactions differ from those generally obtaining in internal trade and in the legal relations confined to Soviet territory. In the final analysis, foreign trade transactions are built along lines fully reflecting the compromise between the Soviet legal order and the property system of the free societies. Its purpose is to permit economic cooperation with the free economy countries, and it does this by incorporating the contract rules and property relations typical for free economy countries into the Soviet foreign trade regulations.

Yet, while the transactional activity of the Soviet foreign trade apparatus is closely modelled on the institutions characteristic of the free economy system, it represents only an external aspect of the law of foreign trade. Behind it stand the system of administrative regulations, the principle of hierarchical subordination, and the principle of the plan, elements which are paramount in the determination of the intrinsic character of the foreign trade relations in the Soviet social and economic order.

The statutum of the Soviet foreign trade contract, thus, can hardly be covered by reference to the law of the place where it is made. It also involves the application of other principles to various aspects of the foreign trade activity. So, for instance,

\footnotetext{
${ }^{40}$ Genkin, supra note 15 , at 59-60.
} 
the Trade Agreement with Laos of December $\mathrm{x}, \mathrm{I} 963^{47}$ provides that "import and export of commodities listed in article 2 shall be effected in accordance with the laws concerning export, import and currency controls in force in each country." A similar provision, somewhat differently formulated, is laid down in article 7 of the Trade Agreement with Ghana (August 4, 1960) ${ }^{48}$ which states that payments for goods delivered under this treaty shall be made in the currency of Ghana, subject to the foreign currency regulations in force in the Soviet Union and in the Republic of Ghana. Article I4 of the same agreement also states that the movement of goods in the territory of each partner is subject to the laws of the state through which they pass. Another aspect of the legal rules governing the contract is contained in provisions of trade agreements or contracts concerning the determination of venue by a method which may be different from that of the law of the place where the contract is made. Yet another class of provisions may be introduced by reference to the status of the juristic persons involved in the trade operations, including provisions regarding their legal capacity as well as the method of representation.

In summary, the law of the contract will also include the law of the territories governing the transport of goods, the law of the country where payment originates, and the provisions which deal with the legal status of organizations and institutions active in foreign trade relations. A foreign trade transaction represents a complex of activities involving various phases and legal relationships, each of them under the rule of its competent law-a feature which cannot be frustrated even by the Soviet tendency to centralization and uniformity. As goods pass from the territory of a socialist country to the free economy area they also pass from one legal regime to another, involving a change not only in formal rules determining the legal consequences of various acts of the parties but also a change in basic concepts such as contract or property.

\section{The Form of Foreign Trade Contracts}

According to article I25 of the Principles of Civil Legislation of I96I, "the form of a transaction entered into abroad is governed by the law of the place where it is made." It adds further that failure to comply with the provisions of the local law shall not render the contract void if it satisfies the formal requirements of Soviet, federal, or republican legislation. ${ }^{49}$

Soviet law is far less liberal with regard to foreign trade contract rules. Compliance with the local rule, if a foreign trade contract was made abroad, would nat make it valid if special Soviet regulations concerning the form of foreign trade contracts were disregarded. Under article I4 of the Principles of Ig6r, "Failure to observe the forms laid down for foreign trade transactions and the order of their signature (art. I25) makes the transaction void."'00

The form of foreign trade transactions is regulated by special provisions. Soviet

\footnotetext{
47 Soviet Laws 1963, No. 10, text no. I24.

${ }^{48}$ Soviet Laws I961, No. 24 , text no. 243.

${ }^{50}$ Cf. R.S.F.S.R. Civil Code, art. 366,9 r.

${ }^{\circ 0}$ Id., art. 265, I2; art. 45 .
} 
law does not prescribe a notarial form for a foreign trade transaction. It must be concluded in writing and must be signed by properly authorized persons. The manner of signature differs, depending upon whether a contract is concluded by a foreign trade organization or by the commercial delegation of the Soviet Union. In the first case, the contract must bear the signatures of two persons authorized to sign foreign trade contracts. This regulation covers both formal contracts, signed by both parties, and letters exchanged with foreign firms or traders containing statements relevant to the terms of contracts. ${ }^{51}$

According to the Soviet government resolution of October $13,1930,{ }^{62}$ transactions concluded by the Trade Representatives of the Soviet Union abroad were under a similar regime. Each transaction of the trade representations called for signatures of two persons. One of those had to be the head of the representation, and the other a person specially authorized to sign such contracts. This system was changed later; and, under the regulations issued by the government on December $26,1935,{ }^{53} \mathrm{Com}$ mercial Representatives (heads of representations) have the right to sign contracts involving values up to 400,000 rubles ( 40,000 new rubles). Contracts involving a value higher than this sum may be signed only with the prior authorization of the Foreign Trade Minister or his representative.

Contracts of foreign trade organizations still require two signatures for their validity, including that of the chairman or his deputy and that of another authorized person. The 1935 regulation introduced the novelty that the names of all persons authorized to sign foreign trade contracts be published in Vneshniaia Torgovlia (Foreign Trade), a monthly publication of the Ministry of Foreign Trade. A corresponding provision, assuring the safety of commerce in terms of authority to represent Soviet economic interests in contracts with foreign firms and economic organizations, is frequently included in trade and navigation agreements with other countries. It is often provided that names of the commercial representatives of the Soviet Union be published in the press of the receiving country.

Soviet authors are unanimous in their opinion that regulations concerning the manner in which Soviet trade organizations conclude contracts should be given extraterritorial effect. It is claimed that they belong to that complex of legal rules which constitute the part of the statutum personale of Soviet juristic persons. In this sense, it seems that foreign courts will assign them a proper role in the determination of the validity of contracts. It also seems true, however, that respect for the Soviet regulations concerning the forms of contractual obligations will at times be less absolute than the Soviet law would require. There might be instances where, in the interest of the security of commerce, foreign courts may be satisfied with the observance of the lex loci contractus, which may be less strict than that provided by the Sovict law.

Some Soviet foreign trade and navigation agreements contain regulations dealing

${ }^{51}$ Statutes of the Foreign Trade Organization Machineksport, 1952 VNEshninis Tongovila No. 5.

${ }^{52}$ Soviet Laws 1930, No. 56, text no. 383 .

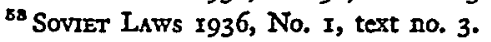


with the question of the form of foreign trade transactions. A typical example of such a regulation is the General Conditions of Delivery of January 30, 1947, agreed upon by the Soviet Trade Delegation of the Soviet Union in Sweden and the General Swedish Association of Exporters. It specifies that all orders for delivery of goods be made in writing and signed by persons legally entitled to represent the firm which makes the order. Once the order is embodied in a written form and accepted by the other party, all previous agreements, whether oral or in writing, lose their validity. Amendment, amplification, or change of such agreements also require a written form. ${ }^{54}$ The same provision found its way into the General Conditions of Delivery, which govern trade relations between the socialist countries (sections I-3) ${ }^{55}$

\section{The American Trader in the USSS.R.}

Soviet and American traders are permitted to operate in the U.S. and in the U.S.S.R. exclusively for the purpose of making contracts with their partners in the other country. It is within the framework of the foreign trade procedures that article 2, point 3, speaks of the governments' promoting cooperation' "between interested organizations and enterprises of the two countries with a view towards the realization of projects for the development of natural resources and projects in the manufacturing industries." This provision does not envision a participation in the development of the economies of either of the parties by means of direct investment. The instruction of the Minister of Foreign Trade as to the purpose of establishing offices for the representation of American firms in the Soviet Union makes it clear that American firms may maintain such offices only for the purpose of foreign trade. They may apply for the allocation of office space if they have concluded especially large commercial transactions with foreign trade organizations of the Soviet Union. In addition to the required number of Soviet citizens (probably as technical staff), American firms in the Soviet Union may not employ more than five Americans as their personnel. "In this connection," so runs the appropriate instruction of the Ministry of Foreign Trade,

it will also be considered that the offices will effectively assist Soviet foreign trade organizations in the development of Soviet exports, including machinery and equipment, and also in the import of machinery and equipment that is technologically modern, and in familiarization with the newest achievements of world technology. ${ }^{66}$

From a general point of view, the U.S.Soviet Trade Agreement is a continuation of the traditional attitudes of the Soviet government toward the scope of the economic cooperation of foreign traders with Soviet economic organizations. It is strictly confined to partnership in foreign trade operations. The Resolution of the Central Committee and of the Council of People's Commissars of January 3I, I93I provided that it was within the jurisdiction of the Council of People's Commissars of the U.S.S.R.

\footnotetext{
"Soiuzneftexport v. A. Maroni and A. Keller, Ramzaitsev Vo vneshnetorgovoi Arbitrazhnoi Kommissii, r96I VNeshniaia Torgovlis No. 7, at 38-39.

${ }^{85}$ Grzybowski, supra note 18 , at 46-47.

${ }^{80} 67$ BuLt. 6or.
} 
to establish general conditions for the admission of foreign companies to business and economic activities in the Soviet Union. ${ }^{57}$ However, when the government's Order was issued on March II, I93I, it became clear that the government's policy was to exclude foreign companies and business firms from economic life in Russia and to limit their activities exclusively to foreign trade operations. ${ }^{58}$ The Order provided that:

Foreign trade, industrial and other economic organizations (societies, companies, etc.) and also individual persons, who own trade, industrial and other economic enterprises abroad, may not be admitted to trade operations on the territory of the U.S.S.R., and may not be permitted to establish for that purpose agencies, offices, branch offices, etc., otherwise than with a special license from the People's Commissar of Foreign Trade.

Without such a license neither Soviet economic organizations nor individual Soviet citizens were permitted to enter into any commercial or labor relations with, or to represent the interests of, such foreign organizations or businessmen.

In contrast with this rigorous and strict attitude towards admission to business activities on Russian soil, the Order adopted a most liberal attitude with regard to the business relations of foreign traders with Soviet foreign trade organizations. Foreign legal entities and individual firms were allowed to conduct negotiations and conclude and perform contracts on Soviet territory with Soviet organizations. In fact, the Order of March II, I93I, constituted a final act in the policy of squeezing out foreign organizations from business activities in Russia. It ruled out for all practical purposes admission to Soviet territory of foreign businessmen, corporate and individual, for any other purpose than activity consisting of individual transactions with Soviet foreign trade organizations.

The Order of March II, 1931 still gave the Soviet government in theory the right to admit a foreign business organization to business activity in the Soviet Union. The Principles of Civil Legislation of $196 \mathrm{I}$ ended this situation since they ruled in article I24 that:

Foreign firms and organizations may, without any special permission, effect transactions in the field of foreign trade in the U.S.S.R., as well as connected insurance and accounting operations, with foreign trade organizations and other Soviet organizations empowered by law to enter into such transactions.

This must be read in conjunction with article I22 of the Principles, which provides that foreign citizens enjoy in the U.S.S.R. the same civil law capacity as Soviet citizens. Since the latter are deprived of the right to engage in business activities on their own account, it becomes clear that Soviet law no longer provides a regime in which a resident foreign citizen or a foreign juristic person established in the Soviet Union may engage in business operations within Soviet territory. Admission to residence in the Soviet Union; still possible in the case of a foreign private person, but

\footnotetext{
${ }^{87}$ Soviet Laws 193i, No. 6, text no. 70.

${ }^{88}$ Soviet Laws 1931, No. 24 , text no. 197.
} 
not a foreign juristic person, ${ }^{59}$ is tantamount to a diminution of that person's civil law capacity, particularly as it concerns business activity.

International agreements on' economic cooperation with other countries determine that private persons or juristic entities participating in the economic life of Russia are subject to the rules and conditions established by Soviet legislation. So, for instance, according to article ro of the Soviet-French Trade Agreement of September I3, $195^{60}$ (which reflects the consistent policy of earlier and later navigation agreements):

Notwithstanding the following provisions, French traders and industrialists, individuals or juridical persons, established according to French legislation, while engaged directly or through their representatives in business activity on the territory of the U.S.S.R., as this activity is determined by the legislation of the Soviet Union, shall as regards their persons and property enjoy the same treatment as citizens and juridical persons of the most favored nation.

From this provision it is also clear that French traders and legal entities may retain their capacity to do business in the U.S.S.R. only when they continue to maintain their residence outside the Soviet territory.

The exclusion of foreign business circles from Soviet territory on a permanent basis serves a number of purposes. In the first place, the foreign trade monopoly exercised by the Ministry of Foreign Trade and foreign trade organizations is preserved. Furthermore, and just as importantly, complete control over the formation of Soviet foreign' trade policy is equally guaranteed. Foreign business circles have no contact with the Soviet market and with the Soviet consumer. Both the consumer and the market are represented by the official apparatus of foreign trade administration.

In the case of the U.S.-U.S.S.R. Agreement, the principle of control is expressed somewhat differently. Letters and documents attached to the Agreement make it quite clear that the fact that an American firm was permitted to open a representation in the Soviet Union will not cause the firm to gain additional channels of communication with Soviet business or manufacturing organizations. The letter of the Minister of Foreign Trade of the Soviet Union states that:

It is recognized that from time to time United States businessmen may have problems regarding such facilities which they are unable to resolve through discussions with various trade organizations or other organizations. In such cases officials of my Ministry, as well as those of the State Committee of the Council of Ministers of the U.S.S.R. for Science and Technology, shall be available through their respective protocol sections for assistance in resolving these problems.

The Instructions attached to this letter state in point 5:

On question of the purchase and sale of goods the Office (of an American firm) may communicate with Soviet organizations that do not have the right to operate in foreign trade only through the Ministry of Foreign Trade and shall conduct its

\footnotetext{
${ }^{50}$ Cf. GRzYBowski, supra note 18 , at II3.

${ }^{\circ 0}$ I5 S.D.D. U.S.S.R. 75.
} 
activities in observance of the laws, decisions of the government, instructions, and rules in force in the U.S.S.R.

At the moment when the Trade Agreement of 1972 was being concluded, the foreign business world in the Soviet Union-consisting exclusively of firms already engaged in trade with Soviet trade organizations-was grossly underrepresented. As an American lawyer recently wrote, a comparatively small number of firms had offices in Moscow. ${ }^{61}$ It is unlikely that an expansion of the business community in Moscow will occur as the result of a sudden influx of American trade representations seeking business opportunities on their own in Moscow. Foreign trade organizations of the Soviet Union can just as well be reached in their offices in New York, or through the Soviet Trade Representation' in Washington. While the Agreement expresses the hope that "total bilateral trade in comparison with the period of I969-I97x will at least triple over the three year period contemplated by this agreement," this expectation' is better explained by the hope for a purchasing campaign made by Soviet foreign trade organizations than by an increase of American trade representations in the U.S.S.R. This is indicated by the language of point 4 of article 2 which states that the

Soviet Government of the Union of Soviet Socialist Republics will place substantial orders in the United States of America for machinery, plant equipment, agricultural products, industrial products and consumer goods produced in the United States of America.

That the Trade Agreement is primarily oriented toward the American producer of capital goods is shown by the agreement concerning the establishment in New York City of the Temporary Purchasing Commission for the Kama River Truck Complex. It will assist in the placement of equipment orders for the Complex, preparation and shipment of equipment, training of Soviet experts, assistance to the U.S. companies in negotiating contracts, and assistance to American experts sent to the Soviet Union as technical consultants and coordinators of equipment assembly. ${ }^{02}$

The expected tripling of the total volume of trade to about one and a half billion dollars in the triennium covered by the Agreement will not add importantly to American exports in terms of our total world trade. However, it is clear that neither side, Soviet or American, is quite familiar with the lines of goods which might find acceptance in the markets of the two countries; this familiarity may develop only in the course of cooperation.

\section{Disputes and Arbitration}

The communique on the creation of the Joint U.S.-U.S.S.R. Commercial Commission mentioned as one of the Commission's tasks the working out of an agreement to establish an arbitration mechanism for settling commercial disputes between the

\footnotetext{
${ }^{61}$ Starr, A New Legal Framework for Trade Between the United States and the Soviet Union: The 1972 US-USSR Trade Agreement, 67 AM. J. INT'L L. 63, 73 (I973).

${ }^{62}$ Letter of the U.S. Secretary of Commerce, 67 BurL. 602-03.
} 
two countries. ${ }^{63}$ This promise was not fulfilled. Arbitration of commercial disputes is dealt with in terms of a policy statement, leaving the decision as to the place of arbitration, choice of the commercial arbitration organization, and applicable law to the interested parties themselves. ${ }^{64}$ Section 2 of article 7 provides that should the parties resort to normal judicial processes, in both countries they will be assured all rights in order to appear and prosecute their claims or defend themselves against actions of the other party.

In the historical perspective article 7 is an important innovation in the disputesettling regime which has previously been followed in relations between the Soviet Union and free economy countries. In the first period, when Soviet trade transactions were primarily handled by the foreign trade representations, the usual procedure was to submit a foreign trade contract to the jurisdiction of the courts and of the law of the place where the contract was made, that is, of the place of the formal accreditation of the foreign trade representation. It was a period when the law of the contract was determined in treaties of commerce and navigation. Such treaties stated that unless the parties agreed otherwise the law where the contract was made was the law of the contract. The only exception to this policy was the Interim Trade Agreement with Great Britain (1930) which contained no provision that the parties could agree otherwise. ${ }^{65}$

In the thirties the focal point in foreign trade operations was shifted from Soviet Trade Representations to foreign trade organizations which were domiciled in Moscow and which made their contracts in Moscow. Unless a different agreement was made in the contract itself, the contract came under the rule of Soviet law and. the jurisdiction of Soviet courts. At the same time, Soviet foreign trade organizations making contracts with foreign firms also insisted that all disputes in connection with the contract be submitted to arbitration and, in particular, to the decision by the Moscow Foreign Trade Arbitration Commission. Thus, the end result of the shift from the trade representation as the main contract-making agent to foreign trade organizations was also a shift to the jurisdiction of the Soviet law of foreign contracts and Soviet commercial arbitration.

This system worked well in the inter-war period and in the initial years of the post World War II era. In due course, as Soviet trade-particularly with the members of the Socialist Commonwealth of Nations and Western Europe-began to expand, a new approach was necessary. It was realized that a more systematic and equitable approach to the law of contracts and the resolution of disputes by arbitration was

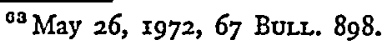

at 67 BuLL. 597 .

${ }^{\circ}$ GrzyBowski, supra note I8, at 89. See the Convention of October 8, 1927, on the Status of the Sovict Trade Delegation in Sweden, which stated that:

Legal problems, which may arise in connection with trade agreements, concluded by the Trade

Delegation shall be subject to the substantive and procedural laws of Sweden, while it is understood that Soviet jurisdiction shall apply to contracts, which, although concluded in Sweden, shall require performance in the Soviet Union.

5 S.D.D. U.S.S.R. 209. 
needed. In 1958, trade with other socialist countries was put under a systematic code of international trade transactions, and the competence of commercial arbitration tribunals was determined according to the nationality of the defendant. ${ }^{60}$ Even prior to that, the Soviet-Japanese Agreement of $1956^{67}$ and the Soviet-Swedish Agreement of $1947^{68}$ had adopted a similar approach. An important development was the Soviet involvement in the effort to provide for an internationally agreed-upon system of commercial arbitration. The Soviet Union, Ukraine, and Byelorussia ratified the Convention on the Recognition and Enforcement of Foreign Arbitral Awards of June 10,1958 and cooperated in the elaboration of the Arbitration Rules of the Economic Commission for Europe of 1966.

The Trade Agreement of 1972 continues the trend toward integration of the Soviet Union into a World Trade Community by accepting the policy of resolution of disputes arising from foreign trade transactions by internationally available commercial arbitration. Article 7 of the Trade Agreement of 1972 provides that:

Both governments encourage the adoption of arbitration for the settlement of disputes arising out of international commercial transactions concluded between natural and legal persons of the United States of America and foreign trade organizations of the Union of Soviet Socialist Republics, such arbitration to be provided for by agreements in contracts between such persons and organizations, or if it has not been so provided, to be provided for in separate agreements between them in writing executed in the form required for the contract itself, such agreements:

(a) to provide for arbitration under the Arbitration Rules of the Economic Commission of Europe of January 20, 1966, in which case such agreement should also designate an Appointing Authority in a country other than the United States of America or the Union of Soviet Socialist Republics for the appointment of an arbitrator or arbitrators in accordance with those rules; and

(b) to specify as the place of arbitration a place in a country other than the United States of America or the Union of Soviet Socialist Republics that is a party to the $195^{8}$ Convention on the Recognition and Enforcement of Foreign Arbitral Awards.

Such persons and organizations, however, may decide upon any other form of arbitration which they mutually prefer and agree best suits their particular needs.

Reference to the United Nations New York Convention on the Recognition and Enforcement of Foreign Arbitral Awards of $195^{60}$ and the Arbitration Rules of the United Nations Economic Commission for Europe of January 20, $x 966^{70}$ is of singular importance for the reorientation of the traditional approach to the resolution of commercial disputes taking place in the Soviet Union. These two documents have laid solid foundations for the international machinery of commercial arbitration in-

\footnotetext{
${ }^{60} \mathrm{GrzyBOw}$ ski, supra note 18 , at 48 .

${ }^{67}$ Starr, supra note $6 \mathrm{r}$, at 76 .

${ }^{\circ 8}$ GrzYBowsKi, supra note I8, at 86.

${ }^{\circ 0} 330$ U.N.T.S. 349.

${ }^{70}$ U.N. ECOSOS E/ECE/625, E/ECE/Trade 81 (January, I966).
} 
cluding the jurisdiction of the Soviet commercial arbitration institutions which were favored under the previous regime.

This new trend, which was first manifested in Soviet participation in the $195^{8}$ Convention on the Execution of Foreign Arbitral Awards, is further emphasized by the fact that the Soviet Union became a party to the European Convention on International Commercial Arbitration of $196 \mathrm{x}^{71}$ and to the European Convention providing a Uniform Law of Arbitration of $1966 .{ }^{72}$ The new orientation in the Soviet foreign trade policy follows the need to seek a broader base in the economic cooperation with the free economy countries. Cooperation is still restricted to the use of the institution of the contract of sale with all its attendant arrangements regarding shipment, delivery, insurance, and services of consultants and technical experts in case of factory equipment and machinery. The Soviet Union, but not other socialist countries, still avoids arrangements which would involve direct investment of foreign capital in the management of developed resources. ${ }^{73}$

While Soviet economic management maintains certain basic positions such as the need for the exclusive control of the industrial and commercial activity in the Soviet Union, it is also clear that the Soviet economy has become, to a far greater degree, a part of the world picture. The Soviet Union needs assistance in modernizing its industries and in developing its deposits of ores, oil, and gas; it also has to depend on imports of grain and foodstuffs in order to feed its populations. There is certainly a greater pressure from the Soviet consumer on the government to maintain an acceptable standard of living. Soviet trade has now become much more of a bilateral flow of goods and services than ever in the past. Hence, the change in attitude and the greater willingness to conform to general patterns of trading and dispute solving.

\section{IV}

\section{Perspectives}

The U.S.-U.S.S.R. Trade Agreement of 1972 is not only a legal document which organizes the regime which will govern American-Soviet trade relations but also a tool containing statements which permit the formation of projections for the future with respect to the growth of trade in terms of the value of mutual exchanges, the classes of goods and services which will be involved, and the forms of cooperation which will be available. The Agreement expresses the hope that, as a result of the

\footnotetext{
${ }^{72}{ }_{4} 84$ U.N.T.S. 349 .

${ }^{73}$ L. Kos-Rabcewicz-Zubxowski, East EuRopean Rules on the Validity of INTERnational Commercial Arbitration Agreements 59 ff. (i970).

${ }^{73}$ For quite some time the Soviet Union has been following a policy of regularizing its relations with the outside world by negotiating bilateral and multilateral conventions, in the first place with the members of the socialist Commonwealth of Nations, and in the second place with the capitalist states, including consular relations, settlement of commercial disputes, and protection of industrial property and copyright. In 1956 the Soviet Union acceded to the Paris Convention on Protection of Industrial Property, while in 1973 it joined the Paris Convention of 1885 on Copyright.
} 
cooperation of the two governments, U.S.-U.S.S.R. trade will triple during the triennium for which the Agreement is effective. Plans for the period beyond the triennium are not stated, but both parties anticipate extending the Trade Agreement for some time or, perhaps, permanently. The Americans also hope that SovietAmerican trade will yield a considerable surplus, thus easing the American balance of payments and improving the employment situation in the U.S. labor market.

The impression that the 1972 Agreement is only a first step in American-Soviet cooperation is received from the Basic Principles of May 26, 1972 which were the subject of agreement during the President's visit to Moscow. Economic ties and commercial cooperation are viewed as important elements in the strengthening of U.S.-Soviet relations. Both governments promised to facilitate cooperation between the relevant organizations and enterprises of the two countries and to work for conclusion of appropriate agreements and contracts, including long-term ones.

The range of goods which the Soviet Union will purchase on the American market is broad. Article 2, point 4, of the Agreement lists machinery, plant equipment, agricultural products, industrial products, and consumer goods produced in the United States. Indeed, these broad categories suggest that practically every area of American industrial activity will have an opportunity to produce and sell on the Soviet market. In the past the Soviet Union bought on American markets, as an emergency measure, goods which were not obtainable elsewhere or not available in sufficient quantities on other markets. One may hope that in view of the mutual granting of credit and financing facilities, the scope and policy of Soviet buying will change. Another hopeful indication as to the future of Soviet-American trade is the fact that the Soviet Union not only plans to buy on the American market but also sees in it an opening for its own exports, structured differently than in the past as regards the classes of goods.

The plans for the future may be gauged from information flowing from two sources. Secretary of Commerce Peterson, speaking on the overall import and export plan, emphasized in terms somewhat more concrete than the Agreement itself that the Soviet Union will buy from the United States machine tools, earthmoving equipment of various kinds, consumer goods, and grain products. At the same time the Soviet Union will deliver energy and substantial amounts of raw materials. ${ }^{74} \mathrm{~A}$ White House fact sheet indicated that the Soviet government plans to buy U.S. equipment to manufacture tableware, that the Kama River Truck Plant Project may also generate contracts for American firms to deliver between $25^{\circ}$ and 500 million dollars worth of machinery, and that grain purchases by the Soviet Union are expected to grow substantially. ${ }^{75}$ The fact sheet also spoke of several large scale joint projects "which were in planning or negotiating stage, including industrial installations for the production of polystyrene, metal fasteners, fertilizers, metal mining and natural gas extraction and transmission." Another source of information is the economic co-

\footnotetext{
${ }^{74} 67$ BUL.. 583 .

${ }^{75}$ Id. at 592-93.
} 
operation planning of the Joint Commercial Commission. In the first place, there is concrete information that the Commission is already considering active cooperation of the two countries in the realization of Soviet gas projects. ${ }^{76}$ In addition, the Commission's responsibility is to arrange for the mutual exchange of patents and licensing.

In terms of organizations and agencies that will handle these various transactions, it is foreseeable that the center of gravity of these transactions will be located in the United States for a number of reasons. Large projects requiring construction of plants and purchases of a great variety of machines and equipment will have to be handled in the United States where the monopolistic Soviet buyers will have the opportunity to review the comparative advantages of purchasing products from the large number of American companies and to choose the type of goods most suitable for the Soviet market. Accreditation of some forty Soviet foreign trade organizations in the U.S. is a comparatively simple matter in a country which is economically polycentric. Such a complete representation of American export interests in the Soviet Union is practically impossible. In addition, all major projects requiring the making of contracts and credit arrangements in the United States will require the cooperation of a number of foreign trade organizations which will be either present in the United States as a matter of general convenience or will be represented in special purchasing commissions handling individual projects. This does not rule out the possibility that similar projects may be handled by consortiums of American exporters negotiating en bloc with Soviet trade organizations, but in view of competing American interests this may not always be possible.

In terms of the forms of economic cooperation between American and Soviet firms, two types of transactions will be employed. The basic form is by a straight salepurchase contract for Soviet or American commodities with or without the use of credit. There will be various aspects of these transactions which will involve insurance and transport, and it is foreseeable that certain standard forms and practices already developed and followed will continue to be adhered to in the future. Some of the contracts may involve complex operations, such as deliveries of entire plants, calling for the supply of blueprints, assembly instructions, and presence of American technicians and consultants. It is also possible-though not very likely-that some of these transactions may amount to turnkey contracts.

The other form of contract will be calling for industrial cooperation, the Soviet equivalent of the joint venture project. This type of cooperation' involves the exchange of cheap, and practically strike-free, socialist labor for machinery, know-how, patents, and marketing in the hard currency countries. The plant an'd the enterprise become the property of the government of the country, and the credit extended by the foreign entrepreneur is repaid by deliveries of the product made in the joint venture factory to the investor who recoups his investment by selling in the West.

Industrial cooperation between the socialist and free market economies has de-

\footnotetext{
${ }^{70}$ Starr, supra note $6 \mathrm{I}$, at $70, \mathrm{n}$. I8.
} 
veloped rather successfully. According to well informed sources, there are some I000 such enterprises existing at this moment, linking Western and Socialist markets. ${ }^{77}$ The advantage of this type of cooperation is that it overcomes the main difficulty afflicting socialist trade, the shortage of hard currency.

In addition to cheap labor, Russia is able to rely on another asset which is of singular significance in contemporary market conditions-the presence of large deposits of gas and ores. This opens a new avenue for economic cooperation. While these various projects-certainly those aiming at opening new sources of raw materials -may generate new orders for American capital goods, it would not be realistic to expect that either the Soviet Union or any other socialist country will increase its trade with the U.S. or the West as a whole in any significant manner. At present there is little in the commodity line which the socialist East can market in the West. It is enough to look at the intra-Western trade as compared to the size of East-West trade to comprehend this. While West Germany has achieved the greatest expansion of its trade with the East, it is still below the level of Swiss trade with the Federal Republic. It is possible and even predictable that the United States will take a larger share of Soviet exports and imports, but overall economic exchange will rise rather slowly and in proportion to the rate of growth of the standard of living in the socialist East.

\footnotetext{
${ }^{77}$ Survey East-West Trade, The Economist (Jan. 6, 1973). See also Wilczrnski, supra note 7 , at 36, 46 (Table $\mathrm{X}$ and passim).
} 